\title{
Extraction of Areas Encompassing Communities in Which People Desire to Live Using Residential-Preference Questionnaire Data 居住地選好アンケートデータを用いた 住みたい街の圏域抽出
}

\author{
Yuta Arai ${ }^{* 1}$, Masaki Aijima ${ }^{* 2}$, Kayo Koide ${ }^{* 3}$ \\ 株式会社リクルート住まいカンパニー \\ SUUMO リサーチセンター \\ 新井 優太

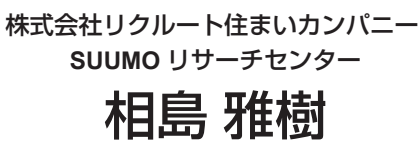 \\ 株式会社リクルート住まいカンパニー \\ SUUMO リサーチセンター \\ 小出 佳世
}

\footnotetext{
${ }^{* 1}$ Recruit Sumai Company Ltd., SUUMO Research Center, arai_yuta@r.recruit.co.jp

${ }^{* 2}$ Recruit Sumai Company Ltd., SUUMO Research Center, aijima@r.recruit.co.jp

${ }^{* 3}$ Recruit Sumai Company Ltd., SUUMO Research Center, kkoide@r.recruit.co.jp
}

\begin{abstract}
Currently, the mainstream online search method used by many real estate portal sites is to show properties in the order of their distance from the nearest rail (including subway) station (i.e., the closest property first, etc.). However, this method does not necessarily enable a person to search for the place of residence that "fits" that person in a logical manner. For example, if it were known that certain community (town) "clusters" had similar characteristics, this would enable a search method whereby selection is made according to community characteristics. In the present study, a network of desirable communities was constructed from desirable residential-preference questionnaire data. Using a modularity optimization method, an attempt was made to extract area clusters having similar characteristics, with closely resembling spatial and psychological distances. As a result, the Tokyo metropolitan area could be divided into 75 such clusters. Each cluster was subsequently characterized using correspondence analysis.
\end{abstract}

Keyword : Complex network, Community detection, Market segmentation, Correspondence analysis

要約：現在の不動産ポータルサイトの多くは, 沿線から駅と順に物件を絞り込んでいくような探索方法が主流である。しかしそ れが, 合理的に自分に合った居住地を探索する方法だとは限らない。たとえば, 似た特徵を持った街の集団が分かっていれば, 街の特徴から選択するような探索方法も可能である。そこで本研究では, 住みたい街アンケート個票データから, 住みたい街 ネットワークを構築し，モジュラリティ最大化による手法を用いることで, 空間的・心理的距離が近く, 似た特徴を持つ街の集 団を圏域として抽出することを試みた。その結果, 首都圏を 75 の圏域に分割することができた。さらにコレスポンデンス分析 を用いることで, 各圏域についての特徵付けを行った。

キーワード : 複雑系ネットワーク, コミュニティ抽出, マーケットセグメンテーション, コレスポンデンス分析

Information : Received 12 August 2019; Accepted 17 November 2019

\section{I. はじめに}

日本における圈域というものを考えたときの 1 つに 「首都圈」や「関西圈」などの大きなくくりがある。今更 言及するまでもないが, 首都圈は 1 都 7 県からなってお り，その中でも杤木県，群馬県，山梨県を除いた 1 都 4
県は東京周辺の生活圈（都市圈）として,「東京大都市 圈」や「東京都市圈」「東京圈」と呼ばれる。

また圈域の解像度をもう 1 段階上げて，東京という 1 つの都市についてみても，23区，26市， 5 町，8村とい う行政区から成り立っており，それぞれの行政区ごとに 異なった特徴を持っている。そのような中で, 例えば地 方から東京都内へ進学・就職・転勤などを理由に引つ越 
しを行うような場合，自分にあった新たな居住地を探す ことは非常に労力を伴う。

近年，引っ越しなどで新たな住居を探す際には，不動 産ポータルサイトを利用することが一般的になってきて おり，瞬時に大量の情報を取得することが容易になった。 現在の不動産ポータルサイトの多くでは，まずは沿線や エリアから駅へと候補地の範囲を絞っていく。その際に, 地縁がないとまずは通学・通勤先への交通アクセスが良 い「知っている街（駅）う有名な街（駅)」から探すのが 一般的ではないだろうか。

しかしながらこのような選択の仕方が，合理的に自ら の条件に適合する街や住まいの探索方法だとは言い難 い。例えば，有名な街だからといって探索者の趣味嗜好 に合っているとも限らない。これが本研究の着想に至っ た動機である。

そこで我々は街の特徴からレコメンデーションできな いかと考えた。しかしながら，ただ単に Jaccard 指数や何 らかの類似度に基づいて特徴が似ている街をレコメンド する場合, 駅前に商業施設が集積しているという理由で, 水戸駅と大宮駅が同時にレコメンドされてしまう可能性 がある。多くの人は，水戸駅と大宮駅のような遠く離れ た場所を同時に提示されても困惑するだろう。そのため 街の特徴が似て㧍り，かつ，人が空間的・心理的に近い と認識している街の集団を抽出する必要がある。

ここではそのための第一歩として, 住みたい街アンケー 卜個票デー夕を用いて，そのような街の集団抽出を試み る。このアンケートでは各回答者に 3 つの住みたい街を 回答してもらっているが，このとき同時に選ばれる $3 つ$ の街こそ，回答者にとって空間的・心理的に近い街だと 考えた。また，同時に選ばれる街がそれぞれ全く異なっ た特徵になっているとも考えづらく，ある程度似た特徵 を持つ街が選ばれると期待される。つまり，同時に選ば れやすい駅の集団が抽出できれば，その集団はそれぞれ 空間的・心理的に近く似た特徵を持つと考えられる。

そこで本研究では複雑系ネットワークの手法を用いる ことで, 街の集団 (= 圈域) 抽出を行う。詳細は後述す るが,このような手法を用いることで複数の回答者に同 時に選ばれやすい街ほど, 高確率で同一の圈域に所属す るような抽出が可能となる。
また，本研究のマーケティングにおける貢献として， 不動産領域に打けるマーケットセグメントの推定がある。 従来の不動産マーケットにおけるエリア分割は経験的な ものであったが，本研究によってそのセグメンテーショ ンを定量的・客観的に示せる。これによって，いわゆる 街の不動産仲介会社が行うようなレコメンデーションを web サイト上で行えるようになる可能性がある。

\section{II. 先行研究}

日本における広い意味での圈域抽出と考えられる都市 圈の研究としては, Kanemoto and Tokuoka（2002）があ る。そこでは, 日本の都市圈定義に公式なものがないた め, 研究者が独自に都市圈定義を提案しているという問 題点を指摘し，新たな都市圈と郊外の定義を提案してい る。しかし本研究では, 都市圈や郊外のような分類では なく, 空間的・心理的に近いと認知されている街の圈域 を抽出したい。

より街という単位に近い圈域の分析では, Kamoshida （2004）でパーソントリップ調查の「私事（買い物など）」 の目的別流動デー夕を用いた生活圈の圈域分析が報告さ れている。しかしながら，この分析では単純に大きな商 業施設があるかどうかなどによって，圈域分けされてし まっている可能性があるし，街の特徴などについては言 及されていない。

一方, 街の心理的評価の地域的差異については, Tone （2009）で報告されている。そこでは，心理的評価の地 域的差異と地域イメージの生成要因に関する分析を行っ ている。データとしてはリクルート社との共同調査のア ンケート個票データが用いられており, 住宅購入者を対 象としている。この論文では, メディア・高級・洗練感 に関する地域イメージ満足度に関して地域間の有意差が あると報告されているものの，地域の区切りを沿線とし て与えている。本研究では似た特徵を持つ地域を, 圈域 として自動的に抽出したい。

また，地理空間と人の認知に関する研究分野の 1 つと して認知地図がある (Lynch, 1960)。特に認知地図研究 を中心にした行動地理学に扔ける MDS の応用事例を紹 
介した論文として Wakabayashi（2006）がある。そこで は 9 力所の地点間の認知距離デー夕を収集し, 現実の地 図との乘離を示している。しかしこのような調査は, 地 点が増えるほど認知距離デー夕の収集は困難であり，本 研究のような広範囲では難しい。

\section{III. データ}

本研究では, 不動産ポータルサイト「SUUMO」を運 営する株式会社リクルート住まいカンパニーが行った 「SUUMO 住みたい街ランキング 2019 関東版」の個票デー 夕を用いる。

この調査は, 関東 (茨城県, 埼玉県, 千葉県, 東京都, 神奈川県）在住の 20 歳〜 49 歳の男女を対象に実施し, 平成 27 年国勢調査の構成に合わせて, 都道府県 $\times$ 性別 ×年代で表 1 のように割り付けてある。

また，同調査はインターネットによるアンケート調査 であり， 1 番目〜3 番目に住みたい街までの 3 つを回答 してもらっている。回答方法は, 画面上にプルダウンリ ストを 3 つ設置し, 都道府県 $\rightarrow$ 沿線 $\rightarrow$ 駅の順で選択肢を
絞り込む形になっている。そのため, 街というのは基本 的に駅を示している。以下では, 街という言葉で統一する。

さらに同調査では，住みたい街以外にも様々な設問が ある。多くは本研究では使用しないため, これ以上の詳 細は割愛するものの, 関連する調査項目として「選んだ 街に住みたい理由」がある。ネットワーク分析で街の圈 域を推定したのち、この設問と組み合わせたコレスポン デンス分析を行うことで, 圈域ごとの特徴付けを行う。

\section{IV. 手法}

\section{1. ネットワークの構築}

本研究では, 前述したデータで選ばれた街をノードと して, ある回答者に同時に選ばれた街同士にリンクを張 ることで，ネットワークを構築する。図 1 にネットワー ク構築のイメージを示す。

まず 1 人目の回答者が街 1 , 街 2 , 街 3 を住みたい街 として挙げたとする。この時, 同時に選ばれた街は空間 的・心理的に近い街とみなし，それぞれの街間にリンク を張る。次に, 2 人目の回答者が街 4 , 街 5 , 街 6 を住み

\begin{tabular}{|rr|rrrrrr|}
\hline & 年代 & 茨城県 & 埼玉県 & 千葉県 & 東京都 & 神奈川県 & 合計 \\
\hline \multirow{3}{*}{ 男性 } & 20 代 & 64 & 172 & 141 & 366 & 225 & 968 \\
& 30 代 & 81 & 212 & 177 & 458 & 277 & 1,205 \\
\hdashline & 40 代 & 95 & 265 & 220 & 501 & 344 & 1,425 \\
\hdashline & 20 代 & 57 & 162 & 132 & 356 & 205 & 912 \\
女性 & 30 代 & 74 & 200 & 169 & 439 & 261 & 1,143 \\
& 40 代 & 88 & 246 & 207 & 483 & 323 & 1,347 \\
\hline \multicolumn{2}{|c|}{ 合計 } & 459 & 1,257 & 1,046 & 2,603 & 1,635 & 7,000 \\
\hline
\end{tabular}

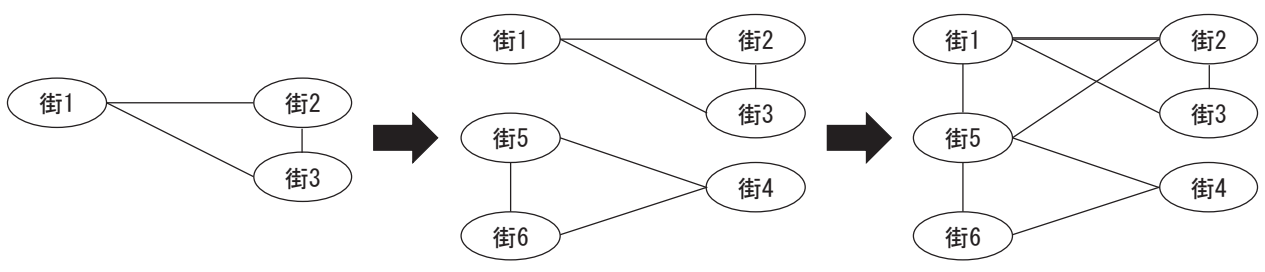


たい街として挙げたとする。これらの街間にも同様にリ ンクを張る。そして 3 人目の回答者が街 1 , 街 2 , 街 5 を挙げたとすると街 1 , 街 5 と街 2 , 街 5 の間にリンク が張られ，それぞれ別々のネットワークになっていた街 1〜3 と街 4 6が1つの大きなネットワークとしてまと まる。この手順を繰り返すことで，ネットワークを構築 していく。

またこの時, 街 1 と街 2 の間にはすでに 1 人目の回答 者の段階でリンクが張られているため， 2 本目のリンク が張られることになる。この場合，重み２のリンクとみ なすことで，ほかの街間よりも結びうきが強いとみなす ことができる。そのため, 複数人に重複して同時に選ば れる街ほど結びつきが強くなり，同一圈域として抽出さ れやすい。

アンケート設問では， 1 番住みたい街 3 番目に住み たい街となっているが，ネットワーク構築を行う上では これらの順番は特に用いず，対等に扱う。このようにし て構築したネットワークは, 重み付き無向ネットワーク となる。

\section{2. 圈域の抽出}

(1) モジュラリティ

本研究では, 冒頭で述べた「圈域」を抽出するために, Newman（2006）によって提案された指標であるモジュ ラリティ $Q$ を用いる。モジュラリテイは，ネットワーク の与えられた分割に対して, 圈域内にリンクが多く, 圈 域外へのリンクが少ない分割ほど高い值を示す。

\section{(2) Fast Unfolding 法}

次に，モジュラリティ $Q$ が最大となる分割を得る手法 について説明を行う。モジュラリティ $Q$ が最大となる
ネットワークの分割を厳密に得ようとするとあらゆる 分割パターンについて計算を行わなければならない。そ の分割のパターン数は街数が増えると爆発的に増加する。 そのためすべての分割パターンを調べることは実質不可 能である。そこで，モンテカルロシミュレーションによ る確率的な手法を用いる。

代表的な手法として, 苓欲アルゴリズム（Clauset, Newman \& Moore, 2004） やスピングラス法に基づくアル ゴリズム（Reichardt \& Bornholdt, 2006）などいくつかあ るが, 本研究では Blondel, Guillaume, Lambiotte, and Lefebvre（2008）によって提案された Fast Unfolding 法と 呼ばれる手法を用いる 1 )。

本来この手法では，段階的に大きな圈域を求めるのだ が，そのように求めた圈域の場合，モジュラリティ $Q$ は 最大化されるものの, 関東で 10 個以下程度の大きな圈 域になってしまう。本研究ではもっと細かい圈域を得た いため, 最初の段階で得られた圈域を用いる。

また上述したように, Fast Unfolding 法は確率的な手法 であるため, 最終的に得られる分割が異なる。そのため 本研究では, 10,000 回計算を行い, 最初の段階で最もモ ジュラリティの值が高い分割を用いる。

\section{V. 分析結果}

\section{1. 住みたい街アンケートの回答傾向}

まず初めに, 住みたい街個票デー夕の回答傾向を調べ るために, 回答者の最寄沿線と住みたい街の沿線の重複 度合を調べた。その結果を表 2 に示す。

表 2 中の沿線重複数 0 は住みたい街 3 つ全てを最寄り 沿線上にない街から選んでいるケースを表している。こ

\begin{tabular}{|c|c|c|}
\hline 沿線重複数 & カウント & 割合 \\
\hline 0 & 3,177 & $45.4 \%$ \\
\hline 1 & 1,761 & $25.2 \%$ \\
\hline 2 & 941 & $13.4 \%$ \\
\hline 3 & 1,121 & $16.0 \%$ \\
\hline 合計 & 7,000 & $100.0 \%$ \\
\hline
\end{tabular}


のことから, 半数以上の回答者が最寄沿線と同一沿線上 から住みたい街を 1 つ以上挙げていることがわかる。ま た今回の集計では駅と沿線の名寄せを行っていない。そ のため, 東京駅は山手線や京浜東北線をはじめとする多 くの沿線が乗り入れているが, 回答者が山手線の東京駅 と挙げた場合は山手線としか扱っていないため，実際に は沿線の重複度合としてはもっと高くなることが想定さ れる。このことから, 通勤や通学で利用する沿線上の, ある程度知っている街, つまり心理的距離の近い街が選 ばれやすい傾向にあると考えられる。

次に, 回答者の最寄駅と 3 つの住みたい街間の距離に ついて調べた結果を図 2 に示す。まず，図 2 左をみると わかるように, 最寄り駅から直線 $10 \mathrm{~km}$ 以内の住みたい 街を選んでいる回答が約 10,000 件あり，全回答のうちの 半数近くを占めることがわかる。直線距離で $10 \mathrm{~km}$ とい うのは, 山手線だと上野-渋谷, 中央線では東京-中野, 京浜東北線では川崎-横浜間に相当する（ただし，いずれ も若干 $10 \mathrm{~km}$ には満たない)。

次に，図 2 右を見るとわかるように，3つの住みたい 街間の距離関係としては $10 \mathrm{~km} \sim 20 \mathrm{~km}$ の組み合わせが 最も多く, 3 街間の距離関係が $30 \mathrm{~km}$ 以下の組み合わせ で全回答の約半数を占める。

ちなみに，住みたい街 TOP3 である横浜，恵比寿，吉 祥寺を選んだ場合，3街間の距離は約 $61 \mathrm{~km}$ であり，3 街間の距離が $61 \mathrm{~km}$ 以上となるような駅の組み合わせは
全回答の $25 \%$ に満たない。このことから，住みたい街と しては, 自分がよく利用する沿線上の空間的距離の近い 街が選ばれる傾向にあると考えられる。

\section{2. 住みたい街ネットワークの圏域}

今回の個票データから得られた街の数は 1,325, リン ク数は 21,000 である。しかしながら，このネットワーク は全ての街が連結しているわけではなく，全部で4つの 連結成分に分かれている。なぜそのようなことが起こる のかというと，ある一人の回答者にしか選ばれなかった 3つの街があると，その 3 つだけトライアングル構造の ネットワークとして分離してしまう。ただし，そのよう な回答は非常に少ないため除外し，本研究では最も大き な街ネットワークを構成している 1,318 駅を対象に Fast Unfolding 法を用いて圈域の分割を行う。

得られた分割のモジュラリティ $Q$ 值は 0.44 であり, 75 の圈域に分割された。すべての圈域を図示することはで きないため, 住みたい街上位 10 の街が所属している圈 域を図 3 に示し，これら圈域のネットワーク特徵量を表 3 に示す。

まず図を見るとわかるように, 横浜圈域（横浜・武蔵 小杉・鎌倉が所属), 恵比寿圈域 (恵比寿・新宿・品川が 所属), 吉祥寺圈域 (吉祥寺 - 中野 - 三鷹が所属), 大宮 圈域（大宮・浦和が所属）の 4 圈域に分かれている。ま た，IV-1でも触れたように，同一沿線上の街は同じ圈域
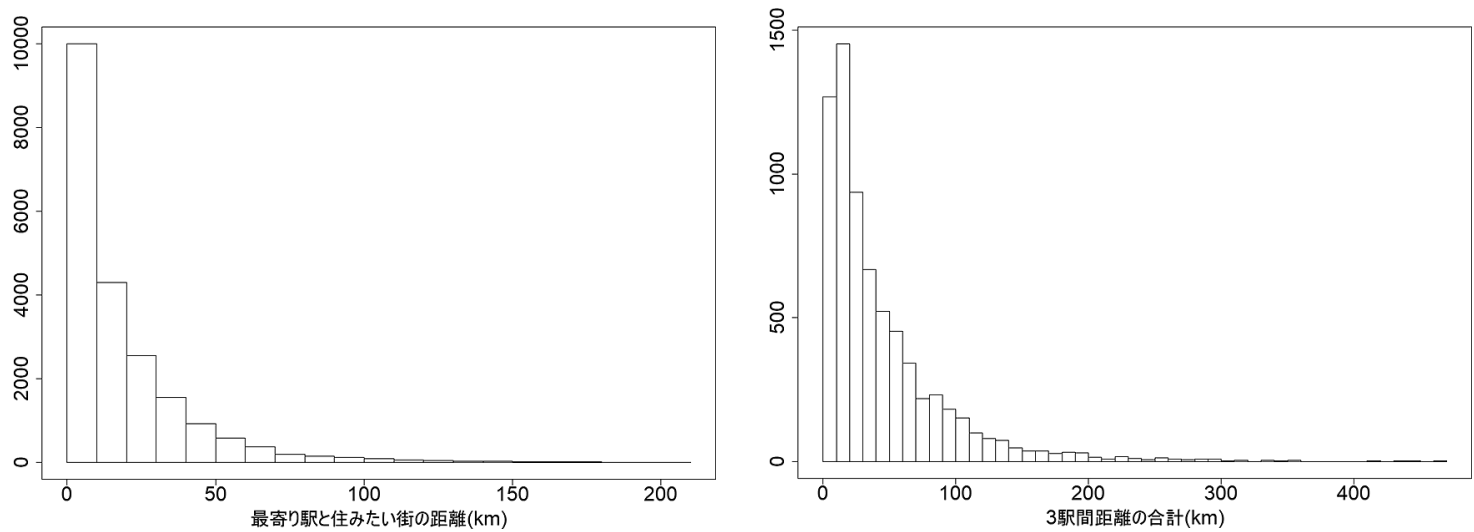
に所属する傾向はあるものの，県境で分断されている沿 線も見られる。例えば東急東横線では新丸子駅〜横浜側 は横浜圈域に属しているように見えるが, 渋谷〜多摩川 は別圈域となっている。

次に, 表 3 をみるとわかるように, 横浜圈域は所属す る街の数が多いものの, リンク数が少ないために疎なネッ トワーク構造をしていることがわかる。逆に大宮圈域は 所属する街の数こそ少ないものの, 最もクラスター係数 が高く, 密度の高い構造が示唆されている。このことか ら, 大宮圈域に所属する街に投票している回答者の多く
は，似たような組み合わせで投票する傾向にあるとわ かる。

\section{3. 抽出された圈域の特徵付け}

III で述べたように, 本研究で用いたアンケート調査で は，住みたい街を選んだ理由についての設問が 37 項目 ある。そこで，これらを用いて得られた圈域についての 特徵づけを行う。全項目を示すことは困難なため, 抜粋 した 14 項目について上記圈域ごとに選択された特徴の 回答率を集計し，表 4 としてまとめた。表 4 から 4 つの

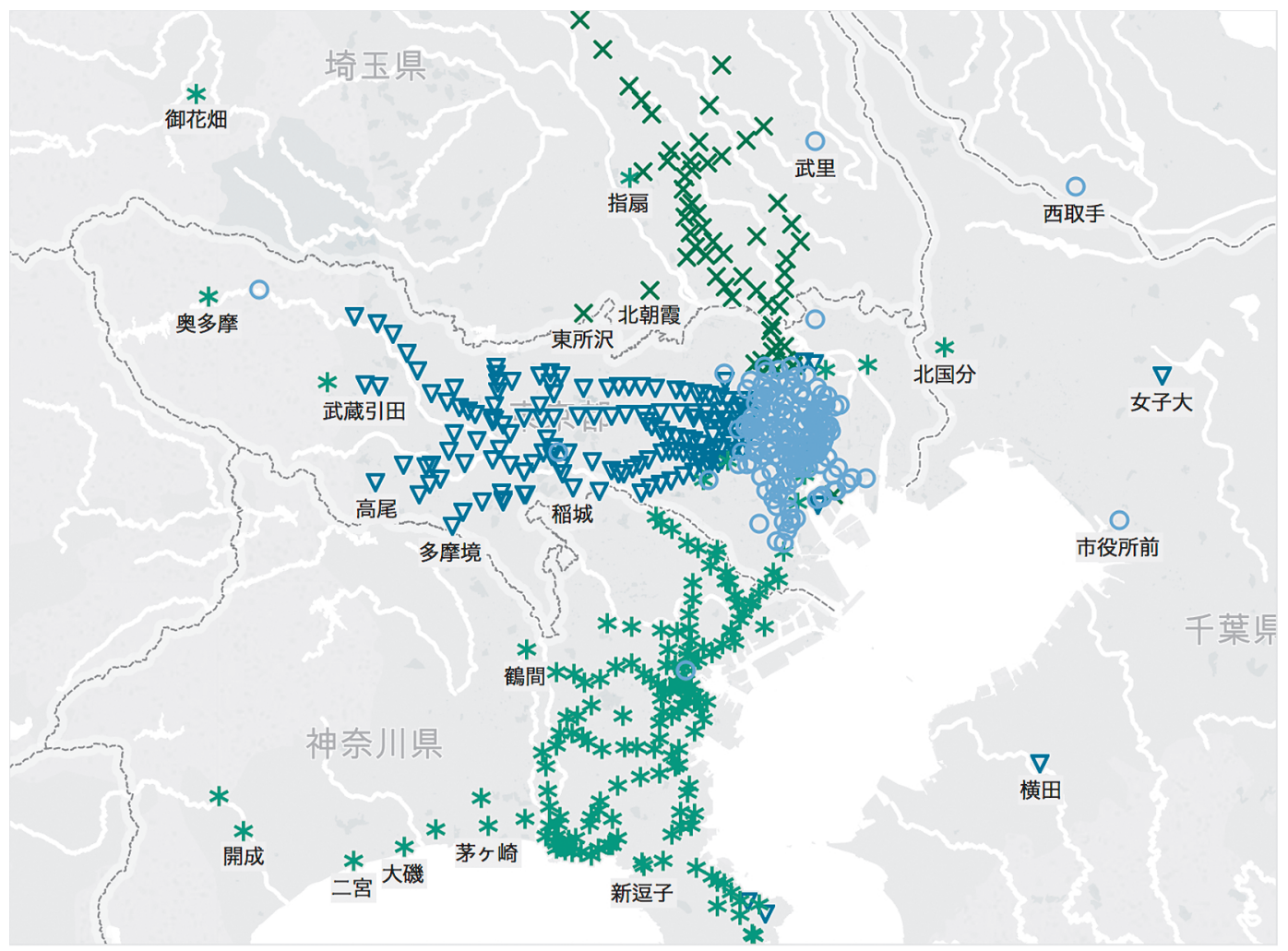

\begin{tabular}{|c|c|c|c|c|c|}
\hline & 駅数 & リンク数 (重み無) & リンク数 (重み有) & クラスター係数 & 平均最短経路長 \\
\hline 横浜圈域 & 181 & 1,030 & 2,176 & 0.276 & 2.445 \\
\hline 恵比寿圈域 & 162 & 1,317 & 2,956 & 0.338 & 2.214 \\
\hline 吉祥寺圈域 & 154 & 734 & 1,651 & 0.300 & 2.552 \\
\hline 大宮圈域 & 59 & 261 & 831 & 0.387 & 2.196 \\
\hline
\end{tabular}




\begin{tabular}{|c|c|c|c|c|}
\hline 街の魅力 & 横浜圈域 & 恵比寿圈域 & 吉祥寺圈域 & 大宮圈域 \\
\hline どこにいくにも電車・バス移動が便利だ & 28.5 & 35.1 & 35.6 & 32.4 \\
\hline 歩く範囲で日常のものはひととおり揃う & 23.7 & 24.8 & 33.7 & 28.5 \\
\hline デパートや大規模商業施設がある & 24.3 & 22.3 & 21.7 & 28.3 \\
\hline 公民館などの公共施設の使い勝手が良い & 5.7 & 5.1 & 8.0 & 9.7 \\
\hline 物価が安い & 5.1 & 3.0 & 6.7 & 9.3 \\
\hline 住居費が安い & 6.1 & 2.5 & 5.9 & 8.4 \\
\hline 緑や海, 川などの自然が豊富 & 21.6 & 4.3 & 14.4 & 7.7 \\
\hline 犯罪が少ない & 9.7 & 9.6 & 12.0 & 9.4 \\
\hline 自然災害がすくなそう & 7.1 & 9.6 & 14.6 & 16.9 \\
\hline 病院や診療所, 介護施設が充実している & 9.9 & 7.9 & 11.1 & 13.2 \\
\hline 小学校・中学校などの教育環境が充実している & 8.9 & 8.0 & 13.5 & 15.3 \\
\hline 資産価值がありそう & 23.7 & 29.8 & 22.7 & 17.8 \\
\hline メディアによく取り上げられて有名である & 20.7 & 21.9 & 18.0 & 13.7 \\
\hline お祭りなど地域の交流が盛んである & 9.5 & 7.0 & 11.3 & 9.9 \\
\hline
\end{tabular}

表中の数值は圈域ごとに魅力だと回答された割合（\%)を表す

圈域の中でそれぞれの強みを見てみると, 横浜圈域は「緑 や海，川などの自然が豊富」という項目の評価が高い。 これは横浜圈域に鎌倉や逗子方面まで含まれているため だと考えられる。次に吉祥寺圈域では「緑や海，川など の自然が豊富」,「お祭りなど地域の交流が盛んである」 がほかの項目に比べて高い。また，大宮圈域では「自然 災害がすくなそう」，「小学校・中学校などの教育環境が 充実している」といった項目が高く，それぞれ異なった 強みを持っていることがわかる。

ここまでは代表的な圈域についてのみその特徵をみて きたが，より俯瞰的に多くの圈域に関する特徵付けを行 うため，住みたい街ランキング上位 100 以内に入る駅が 所属する圈域について，住みたい理由 37 項目をそれぞ れ集計し，コレスポンデンス分析を行った。その結果を 図 4 に示す。なお，得られた結果に対するイナーシャの 寄与率 (二次元での累積) をみると約 $67 \%$ あ゙あり，ある 程度の説明力を持ったモデルになっている。

図を見るとわかるように, コレスポンデンス分析を行っ たことで, 各圈域の特徵が明確に表れている。例えば, 第 1 象限の印象は,「緑や海, 川などの自然が豊富」,「今 後発展しそう」などの近年開発されている郊外都市，第 2 象限の印象は，「物価が安い」，「自然災害が少なそう」, 「公民館などの公共施設の使い勝手がいい」と言った昔か らの郊外で暮らしのコストパフォーマンスが良いイメー
ジ，第 3 象限は「どこに行くにも電車・バス移動が便利 だ」，「歩く範囲で日常のものは一通り揃う」などの下町 で暮らしの利便性が高いイメージ，第 4 象限は「資産価 值がありそう」，「メディアによく取り上げられて有名で ある」などの心理的評価が高いイメージになっている。

実際, 表 3 でも住みたい街上位である横浜, 恵比寿, 吉祥寺が所属する圈域では, 交通利便や買い物などの日 常利便だけでなく，資産価値やメディア露出などに関し ての高評価が共通している。このことから, 住みたい街 で上位に選ばれるためにはこれらの項目が重視されてい ることがわかる。

\section{VI. 考察}

本研究では, 住みたい街アンケート個票データに対し て複雑系ネットワークの手法を用いることで，空間的・ 心理的距離が近い街の集団を圈域として抽出し, 各圈域 の特徴づけを行った。

まず同一沿線上の街ほど同一圈域として抽出される傾 向が強いとわかった。しかしながら, 単純に沿線で分か れているというわけでもなく，沿線によっては県境や川 によって異なる圈域に分割されることがわかった。例え ば不動産マーケットにおいて，県境や川によってエリア 


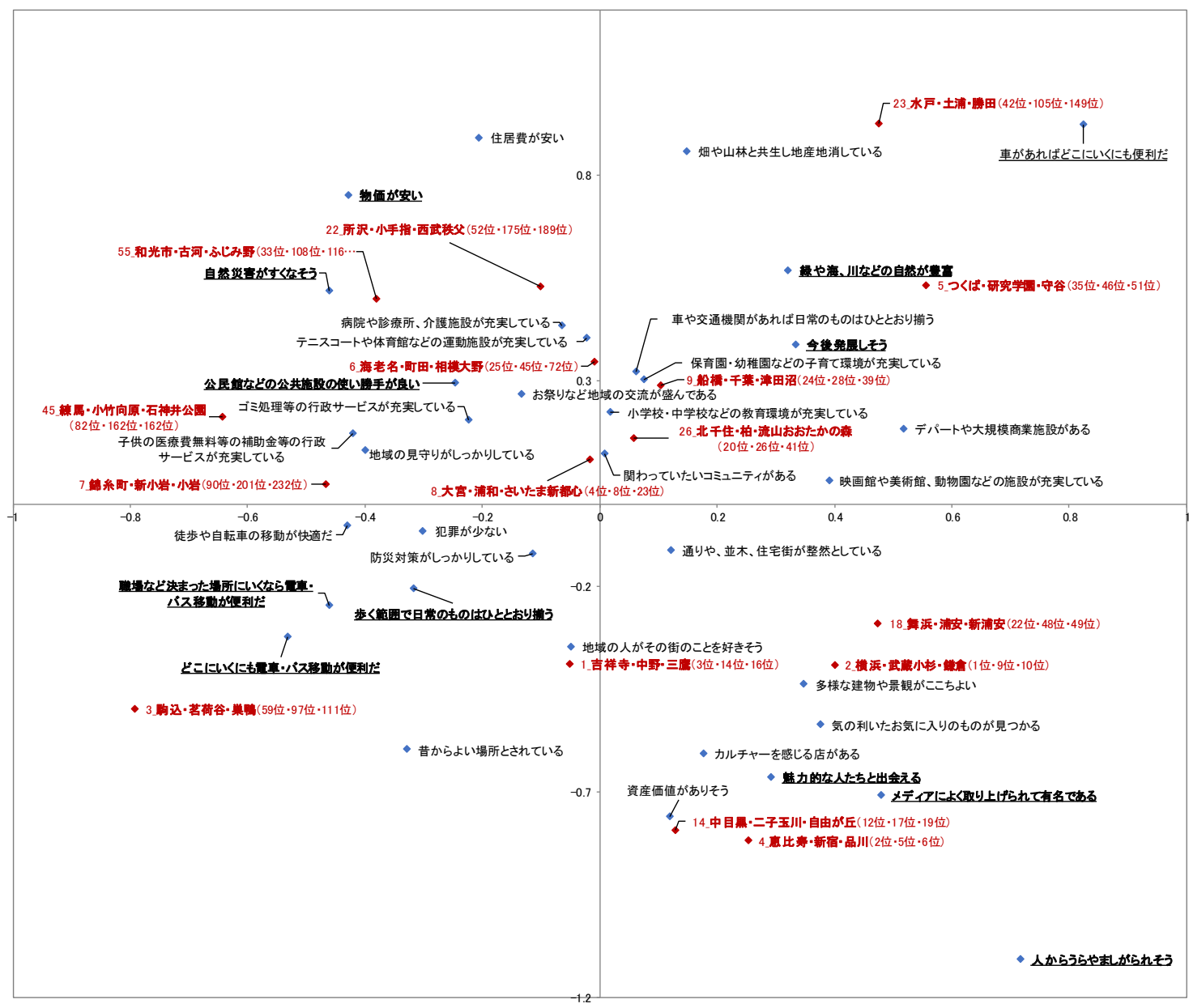

が分断されるというのは経験的に知られてきたことであ るが，今回はそれを定量的に示すことができた。また， 沿線によっては県境や川で県域が分断されないものもあ る。このように，県域で分断されてしまう沿線とされな い沿線があることは非常に興味深い結果であり，圈域別 の特徵をより詳細に分析することで，鉄道沿線イメージ のブランディングやマーケティングへの応用が考えら れる。

次に, 得られた圈域についてコレスポンデンス分析を 行い，圈域の特徴づけを行った。住みたい街上位の街が 所属する圈域の多くは第 4 象限，もしくはその近くに位 置しており，逆に上位の中でも比較的下位の街が所属す る圈域は第 2 象限に位置している。このことから，住み
たい街の特徴としては資産価值やメディア露出などが重 視され，居住費や物価の安さ，行政サービスなどは重視 されにくい傾向にあることもわかった。

注

1）本研究に拄ける計算は R（version 3.5.1）とネットワーク分 析用のライブラリである igraph（version 1.2.2）を使用し た。また FastUnfolding 法については, igraphに用意された 関数である multilevel.community を使用した。

\section{References}

Blondel, V. D., Guillaume, J., Lambiotte, R., \& Lefebvre, E. (2008). Fast unfolding of communities in large networks. Journal of Statistical Mechanics: Theory and Experiment, 2008(10), 10008.

Clauset, A., Newman, M. E. J., \& Moore, C. (2004). Finding 
Peer-Reviewed Article 査読論文

community structure in very large networks. Physical Review E, 70, 066111.

Kamoshida, T. (2004). Toshi, kokudo niokeru ken'ikibunseki no shuhou: Kyakkannteki, teiryouteki na bunsekishuhou to sono katsuyoukanousei. Best Value, 7, 22-25.（鴨志田武史 (2004). 「都市・国土における圈域分析の手法一客観的，定量的な分 析手法とその活用可能性一」『Best Value』7, 22-25) (In Japanese)

Kanemoto, Y., \& Tokuoka, K. (2002). Proposal for the standards of metropolitan areas of Japan. Journal of Applied Regional Science, 7, 1-15. (金本良嗣・徳岡一幸 (2002)。「日本の都 市圈設定基準」『応用地域学研究』7,1-15) (In Japanese with English abstract)

Lynch, K. (1960). The image of the city. Cambridge: MIT Press.

Newman, M. E. J. (2006). Modularity and community structure in networks. Proceedings of National Academy of Sciences of USA, 103(23), 8577-8582.

Reichardt, J., \& Bornholdt, S. (2006). Statistical mechanics of community detection. Physical Review E, 74, 016110.

Tone, R. (2009). Regional difference of residents' subjective evaluation for social-psychological characteristics of residential environment and generation factors of image of town, by comparison of areas along railway lines in Tokyo. Theory and Applications of GIS, 17(1), 111-122.（刀根令子 (2009).「鉄道路線エリア間比較による住環境の社会－心理 的評価の地域的差異と地域イメージの生成要因に関する分 析」『GIS：理論と応用』17(1), 111-122) (In Japanese with English abstract)

Wakabayashi, Y. (2006). Application of multidimensional scaling to behavioral geography: Mainly focused on the spatial analysis of congnitive maps. The Japanese Journal of Behaviometrics, 33(2), 127-132. (若林芳樹 (2006).「行動地理学への多次元 尺度構成法の応用一認知地図の空間分析を中心として一 『行動計量学』33(2), 127-132) (In Japanese with English abstract) 